\title{
SPECIFIC TYPES AND CATEGORIZATIONS OF BROWNFIELDS: SYNTHESIS OF INDIVIDUAL APPROACHES
}

\author{
Kamila TURECKOVA ${ }^{1}$
}

DOI: $10.21163 / \mathrm{GT} \_2021.162 .03$

\begin{abstract}
:
The issue of brownfields, abandoned and unused sites and buildings, is repeatedly accentuated by the experts with respect to the predominant contemporary urbanistic, environmental, economic or social approaches. Despite the fact that the issue of brownfields was scientifically discussed from various points of view, there are still some general findings that have not been fully covered and processed. One of them is the basic typology of brownfields. The aim of the paper is thus to synthesize the heterogeneous typology of brownfields into a logical and comprehensive framework that would reflect its content and classification comprehensiveness. Such synthesis of typological schemes and their objective categorization into standard classes and groups reflects the general requirements regarding the characteristics of brownfields and enables to define the individual brownfields according to a uniform method and analyze them using the standardized categories. The presented categorization of brownfields is based on the already used classification which is then extended with new groups that are unified in terms of their content. The next part of the paper is the definition of specific types of brownfields such as, for example, blackfield, bluefield or goldfield and others.
\end{abstract}

Key-words: Bluefield, Blackfield, Greyfield, Goldfield, Whitefield, Brownfield categorization.

\section{INTRODUCTION}

Brownfields, the reasons for their development, the effects of their existence, resulting issues and suggestions how to deal with them are all current topics both for professional and non-professional discussion across public and private subjects and institutions interested in this issue. Brownfields, withing the current (modern) approach and concerning the economic development and current dynamic enhancement of life quality, are perceived to be a significant, yet a specific feature of regional development and spatial arrangement of the environment in which we live (Turečková et al., 2021). Nowadays, brownfields represent urban specifics of human origin that include abandoned properties that do not serve their original function and are fully or partially unutilized. Alker et al. (2000) or Yount (2003) define brownfield as a property that is underused, neglected, or possibly contaminated, and is the remains of industrial, agricultural, residential, military or other activities. Ferber et al. (2006) define brownfields as the properties that are impacted by their former utilization, are abandoned or unutilized, have potential contamination issues and are usually located in built-up areas (in the vicinity of the settlement areas) and in order to be meaningfully utilized they require active (private or public) intervention. Such properties may be the remains of industrial, agricultural, military, transport, religious, housing and other activities (e.g. community facilities) be it either in the form of land or buildings (sites) that are located anywhere within the cadastral area of the cities and municipalities (Krzystofik, Kantor-Pietraga \& Spórna, 2013 or Turečková et al., 2019).

\footnotetext{
${ }^{1}$ School of Business Administration in Karvina, Silesian University in Opava, Univerzitni Nam. 1934/3, 73340 Karvina, Czech Republic, tureckova@opf.slu.cz.
} 
Brownfields were researched from various points of view, for example in relation to sustainable development (Vráblík, 2009; Martinát et al., 2016 or Heatherington et al., 2019), urbanism and city planning (Vojvodíková, 2014; Kirschner, 2006; Bergatt Jackson and Votoček, 2010; Navrátil et al., 2018 or Turečková et al., 2018); environmental and geographical aspects (Klusáček et al., 2011; Duží and Jakubínský, 2013; Frantál, 2015; Martinát et al., 2015). A range of studies are dealing with the impact of brownfields on the values of the residential properties in their vicinity (De Sousa, 2000; Mihaescu and vom Hofe, 2012; Sun and Jones, 2013 or Turečková et al., 2017), on the development limits of residential housing in relation to brownfields (Spilková and Šefrna, 2010) or the impact on the existence of brownfields regarding the utilization of unbuilt empty sites in the open countryside (Bartke a Schwarze, 2015).

The list of other implications of the existence of brownfields for other research objects is quite extensive and it is not the purpose of this article to follow this topic. We can conclude that the majority of the papers focusing on the issue of brownfields encourage the process of their regeneration. Abandoned and unused buildings and sites are both objectively and subjectively related to a wide range of undesirable environmental, social and economic effects and impacts that become more urgent with the delay of their regeneration (Turečková and Chmielová, 2018). There are many reasons to get involved in reusing brownfields. Among the key ones are the fact that brownfield regeneration contributes to sustainable urban development (Vráblík, 2009), reduces the negative effects of suburbanization with urban sprawl (Jackson, 2002) and preserves the local, temporal and urban continuity of residential, social and social and environmental structures of the landscape. Reflecting all the above-mentioned the regeneration of brownfields is socially desirable and appropriate (Schädler et al., 2011).

As it was mentioned above, the issue of abandoned and unused buildings and sites is relatively well-known yet it still offers some space for further investigation and scientific research. This paper is focusing on one such overlooked issue related to the existence of brownfields. The paper is not intended to be purely research-focused yet its objective is to synthesise the more or less fragmented typology of brownfields into a uniform, logical and comprehensive framework while maintaining completeness in terms of the content and classification. At this point, however, it is necessary to add that the categorization of brownfields itself is subject to a number of spatial and temporal constraints. Such a synthesis of typological patterns supplemented with definitions of specific types of brownfields has not yet been published (based on the bibliographic search of the domestic and foreign resources) and so it creates a large space for future use. The categories of brownfields created are based on the already used categorization that is extended if necessary and unified in terms of their content. The categorization of specific types of brownfields on „one spot“ including blackfield, greyfield, goldfield, bluefield and whitefield is unique. The above mentioned reflects the motivation why this paper was written.

The paper is divided into five parts. The introductory part is followed by the chapter presenting the applied methodology and introducing the authors who in their concepts of the typology of brownfields created areas that were indirectly adopted or modified by the author of this paper. The third part called Special types of brownfields defines the individual alternative terms used for the concrete types of brownfields such as blackfields, greyfields, bluefields, goldfields and whitefield. The fourth chapter refers to the general categorization of brownfields and suggests ten basic classification areas that can be applied when doing a standard categorization of brownfields. The last part, the Conclusion, closes the paper with a summary of the presented text and states the objective with which the paper was composed.

\section{METHODOLOGY}

The presented paper is entirely theoretical and it aims to unite, synthesize and categorize brownfields by researching the expert resources of scientific nature, both Czech and foreign, and comparing them according to their most frequently used characteristics, properties and features. The current non-uniform classification as well as the terminological disunity of objectively used types of 
brownfields leaves space for unintentional confusion of some of the types of the classification schemes. The unification of the typology of brownfields on „one spot“ will also enable to define the selected brownfield according to the categorization that has not been available up to now to such extent that will be presented in the following chapters of this paper.

The first chapter focusing on the specific types of brownfields is based on the concrete search of authors who provided their expert comments on the given type of brownfield. This traditional scientific approach is combined with information that is specific for these types of brownfields yet represents general knowledge.

The sphere of categorization and classification of brownfields according to various criteria is rather extensive and often overlaps semantically. The traditional classification quoted in the Czech texts mostly comes from the domestic authors such as Kadeřábková and Piecha (2009), Šilhánková et al., (2006) and Dvořáková Lišková, Vojvodíková and Majstríková (2016). And also the following authors like Vráblík (2009), Jankových-Kirschner (2005), Doležalová (2015) or Jackson et al., (2004). Selected categories of brownfields are also specified in the National Brownfield Regeneration Strategy or in Brownfields Handbook (2006), or are mentioned in other documents (e.g. in the individual strategies for brownfield reuse in the regions of the Czech Republic). As far as foreign resources are concerned, the categorization according to the CABERBET project from 2006 is frequently quoted (also termed as ABC model). The presented synthesis of brownfield typology is also based on information from the classification and categorization of brownfields by the selected foreign authors (Norrman et al., 2015; Pizzol et al., 2016; Ferber et al., 2006; Bakker, 2016; Yakhlef and Abed, 2019 or Naveed et al., 2018). It needs to be said that the Czech authors mentioned above also reflect the foreign brownfield typology in their approach as far as the classification of brownfields is concerned which in no way differs from the international concept.

The brownfield categorization stated below was created by a synthesis of three approaches: (1) it applies the already used classification but makes it more specific or partly adjusts it and supplements it; (2) it unifies in terms of terminology and content the objectively identical classification that is used differently by various authors and lastly (3) the author supplements the classification with her own categories that she considers essential as far as the determination of factors and description of individual brownfields are concerned, in particular in the case of analytical work and empirical research focused on brownfields. The categorization scheme presented in Table 1 (Chapter 4) was compiled through a synthesis of adopted (to a certain extent, yet not fully) brownfield typology from authors and resources mentioned above and own author's invention.

\section{SPECIAL TYPES OF BROWNFIELDS}

To reflect the need to specify brownfields according to their significant characteristics, derived terms that could be used with the word ,-field“ were created. Thus the expressions like blackfields, bluefields and others started to be used. These terms represent abandoned and underused sites or buildings (brownfield) with a specific particularity that is directly and immediately specified by using the given „word derivative“. So far we recognize four specific types of brownfields. They are (1) blackfield; (2) greyfield; (3) bluefield; and lastly (4) goldfield (the use of the term „whitefield“ is ambiguous). By contrast, we need to clearly distinguish greenfield (greenfield site) which is the very opposite to brownfield from the urban viewpoint and it represents unoccupied site (undeveloped, unused) with agricultural or farmland (Kibert,2008) or former natural areas, which after the amendment of the spatial plan was defined as a developing area intended for residential, commercial or industrial development (Institute for Ecopolitics, 2006). Specific types are the so-called derelict greenfields that are represented by abandoned agricultural areas (former gardens, plantations, planted fields, etc.) that were formerly actively used for agriculture but now lie fallow. These areas are the most suitable ones as far as functional transformation is concerned (Krzystofik, Kantor-Pietraga \& Spórna, 2013).

By blackfields we understand abandoned areas with an extreme ecological burden that restricts their new use to a significant degree and which considerably increases the costs and/or prolongs the 
regeneration process. The ecological burden is characterized mainly by contamination of soil, groundwater and subsurface water or other segments of the environment, as blackfields are mostly of industrial, mining or military origin. Extreme contamination of these sites by toxic or poisonous substances poses a significant risk to the environment and human health, which requires potential immediate intervention and such dangerous and undesirable situation needs to be eliminated. According to Krzystofik, Kantor-Pietraga and Spórna (2013), blackfields are represented by all types of landfills, post-flotation reservoirs, post-mining sites (of coal, some selected minerals or oil) that are chemically or radioactively contaminated, etc. Other sites defined as blackfields are abandoned reservoirs or sites that are heavily contaminated by pesticides or other chemicals used in agriculture, or sites with service or laboratory buildings where undesirable chemicals were used. Blackfield thus represents the worst type of brownfield (Fig. 1).

The term greyfield refers to brownfields that surround vast areas of asphalt concrete used as large car parks and transport infrastructure for the nearby sites and buildings (Moeller, 2011). It can be deduced that greyfields are abandoned and malfunctioning sites of public services (especially retail and commercial shopping centres, office buildings or compact residential areas). The reason why they emerged was the relocation of commercial and shopping activities to bigger, more modern shopping areas, and office and housing services to more lucrative areas within the developer projects, mainly in the suburbia. Greyfields do not show a high degree of contamination, do not require costly rehabilitation and thus can be used for new investment without any needless costs. The benefit of greyfields is that they generally have the basic infrastructure (water supply, electricity, heating, gas supply, the site is connected to the sewage system, and another technical and non-technical infrastructure is available) and they are located in the vicinity of the city centres and municipalities. The topicality of greyfield regeneration, especially if supported by the public sector, may reflect the undesirable manifestation of the so-called urban sprawl.
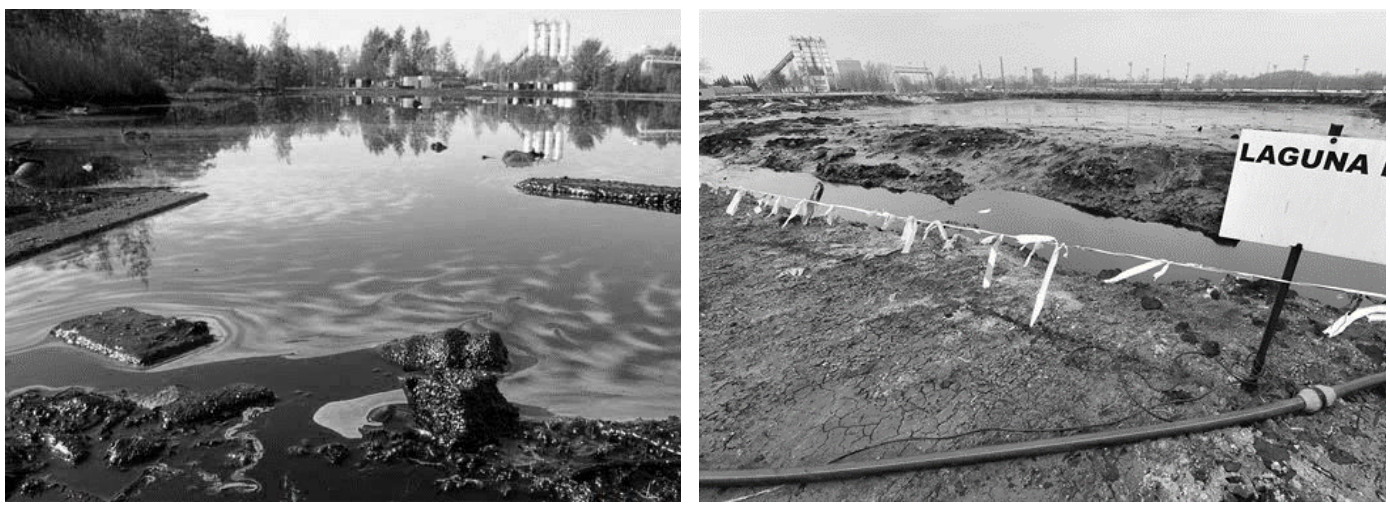

Fig. 1. Blackfield Petroleum lagoon in Ostrava, Czech Republic (Source: idnes.cz; petrol.cz).

Note: The lagoons were one of the biggest environmental burdens in the Czech Republic. It was a landfill for waste from a refinery and a chemical plant that processed mineral oils. All sludges from oil lagoons have already been mined and the site has been stabilized with lime.

Bluefield is a type of brownfield that is located near the water source and its former function was closely related to the use of water or its regulation (mainly flood control). In this context, Pinch and Munt (2002) emphasise that bluefields are underused buildings located between the mainland and „water space“ (river, lake, sea, etc.). Thus, old ports and quays, piers, docks, shipyards, embankments, slipways, barrages, fishpond drains, clogged raceways and others can be also classified as bluefields. The regeneration of bluefields has its specifics that are reflected in the special water source conservation, in the expanding number of people involved (e.g. Water Stream Management, The Ministry of Agriculture and others are involved in the regeneration process) or in their importance for the infrastructure and transport. 
The last type of brownfield, which is the least known yet widely used, is the so-called goldfield. Its potential regeneration presents an extremely profitable investment with a high rate of return. Goldfield is originally a standard brownfield (i.e. it is not goldfield at the very beginning) and it is transformed into goldfield due to an exogenous ,change“. This can be a change in spatial planning, in consumers' behaviour particularly in response to fashion trends or social responsibility, investment incentives and targeted subsidies for companies, newly established effects of urban sprawl, and others. The area of the former Karolina mine near Ostrava city centre is an example of goldfield (Fig. 2), which at the same time used to be a typical blackfield due to its high soil contamination (more in Suchacek, 2019). This site became interesting for the investors after its redevelopment had been finished and an urbanistic competition for its reuse was announced. An attractive project in terms of investments resulted in building ,a new centre“ of Ostrava that gradually interconnected the Forum shopping centre Nová Karolina, office buildings in Nová Karolina Park and residential houses in Rezidence Nová Karolina. The site of Nová Karolina presently generates additional income for the investors and at the same time, the locality contributed to the economic development of the region and boosted the attractiveness of the city.
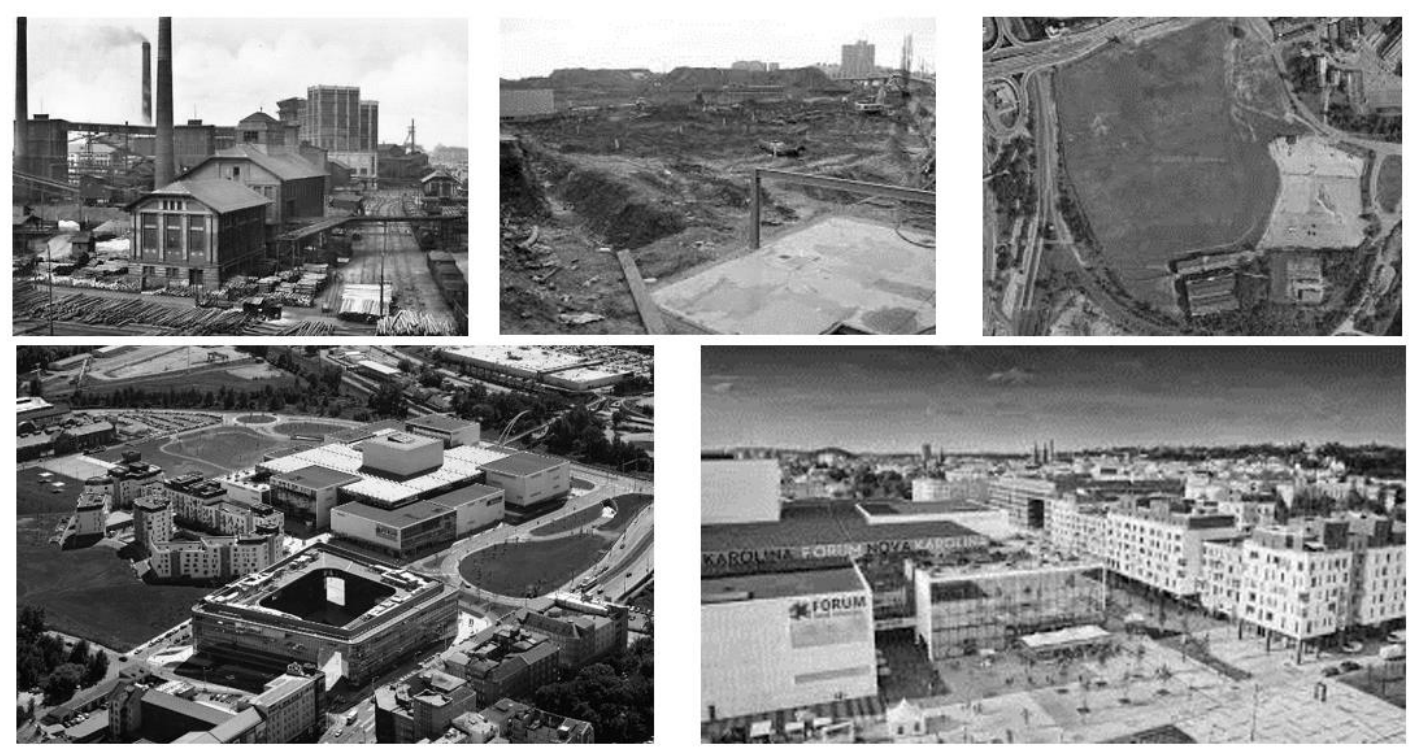

Fig. 2. Goldfield Nová Karolina in Ostrava, Czech Republic

(Source: ostrava.cz; cizp.cz; gemo.cz; fabriky.cz).

From time to time, the use of the term „whitefield“ can be noticed. The international expert resources do not mention this term, in the Czech scientific environment it is defined by Kadeřábková and Piecha (2009). They define whitefield as a brownfield that will be taken care of by the market itself due to its extremely favourable location. If we establish our definition of whitefield as being the counterpoint to blackfield and broaden it with the above-mentioned feature, we can characterise whitefield as a brownfield that is not contaminated, doesn't require any involvement of the public sector in its regeneration process, is located in an interesting and desirable locality and is attractive to be reused by the private sector. Unlike goldfield, its financial rate of return and investment attractiveness is much higher. There is another viewpoint that depicts whitefield as a brownfield that was entirely removed and its existence is not apparent at all at present. It can be said that it is the socalled ,non-original“" greenfield. 


\section{CLASSIFICATION OF BROWNFIELDS; STANDARDIZED CATEGORIZATION SCHEME OF BROWNFIELDS}

As it was mentioned in the introduction, this part of the paper will be focused on the synthesis of the categorization scheme of brownfields. We aim to unify the diverse typology of brownfields into one complex framework that will reflect the basic characteristics of brownfields that are routinely determined with brownfields. The listing of ten categories in which brownfields can be divided is certainly not comprehensive: there are more aspects according which the brownfields can be classified, yet they are not very frequently used and are regionally specific. This means that they are not uniform and do not meet the requirement that the category is universally accepted.

The basic categorization of brownfields thus refers to (1) their original function including the categorization according to the (economic) sectoral classification; (2) area; (3) location; (4) ownership; (5) contamination and ecological burden. Another categorization takes into consideration the perspective of the potential regeneration and within this homogenous group brownfields can be categorized according to (6) the development point of view (class); (7) development potential; (8) the participant of the potential regeneration; (9) type of financing of the potential regeneration and lastly (10) according to the financial attractiveness of the regenerated brownfield, and these individual categories are logically and factually interconnected, both vertically and horizontally. The individual categories will be specified in more detail further in the text (see Table 1 or Fig. 3).

Based on the economic sector, brownfields are traditionally categorized into three groups that reflect the specific functions that were performed by the original site or building, i.e. which type of activity was carried out there and what had been its purpose before it turned into brownfield (concrete subdivision into individual sectors is based on the standardized international categorization of economic activities NACE Rev. 2, for more e.g. Turečková, 2014). The primary sector refers to the activities related to agricultural production (crop or animal) or raw material extraction (underground or surface). The secondary sector includes mainly the brownfields formerly used for industrial production, transport and distribution services, construction and others. Brownfields that are part of the tertiary sector include abandoned and unused buildings formerly functioning as public facilities (education facilities, hospitals, commercial and cultural centres, buildings for business and tourism, restaurant facilities and others), administrative facilities (logistic and commercial), formerly used for services, residential (flats, housing) and others. The last subgroup (not categorized within the sectors) are military brownfields, former chateaus and religious buildings (monasteries, abandoned cemeteries, churches) that refer to their specific type of ownership rather than their former functionality (these specific brownfields were more or less multifunctional).

Based on the area that they occupy, brownfields can be divided into small (up to 1 ha), middlesized (1-10 ha), large (10-100 ha) and extensive ones (with an area of more than $1 \mathrm{~km} 2$ ). Brownfields can be both found in the urban zones as well as rural zones. To better specify the localization of brownfields within the urban zone, we can divide them according to their location in (1) the central parts of cities (inner city zones), (2) in the suburban zones or within the areas of (3) the countryside settlements (smaller municipalities). Abandoned and unused buildings and sites can also be located (4) outside urban areas (i.e. in the rural zones). We can also classify brownfields based on their ownership, i.e. who is the owner of the specific building or site and is entitled to handle the property. We can differentiate between public ownership (the owner of the property is the state, self-governing unit, other public company or public institution, and others.), private ownership, mixed ownership (not honest) and there may occur a situation when the proprietary rights are not solved at the given moment and the owner is unknown. As contamination and ecological burden are both considered as far as ,terminology“ is concerned the identical property of brownfields, we can thus define brownfields (1) without ecological burden - not contaminated, (2) with ecological burden contaminated, when the level of contamination is specified in more detail and (3) brownfields in which we are not simply aware of any objective ecological burden and we do not know whether the property is contaminated or not; then these buildings and sites may be defined as having , an unknown degree of ecological burden - unknown degree of contamination“. 
The description of the second part of the categorization scheme concerning the development potential resulting from the subsequent brownfield regeneration will be directed across the defined groups (horizontally) as such description will reflect more appropriately both the content and factual interconnection of individual types of brownfields: (1) if we consider the building or the site of the present brownfield highly (economically) attractive for its further use that will generate profit after the regeneration or renovation, its development potential is high due to its attractiveness for the private sector which will use private sources (investment) for its regeneration. Such a brownfield may be termed as self-developing as its regeneration results from the activation of its inner potential in response to the requirements of the neighbourhood.

Table 1.

Categorization scheme of brownfields, subdivision and typology.

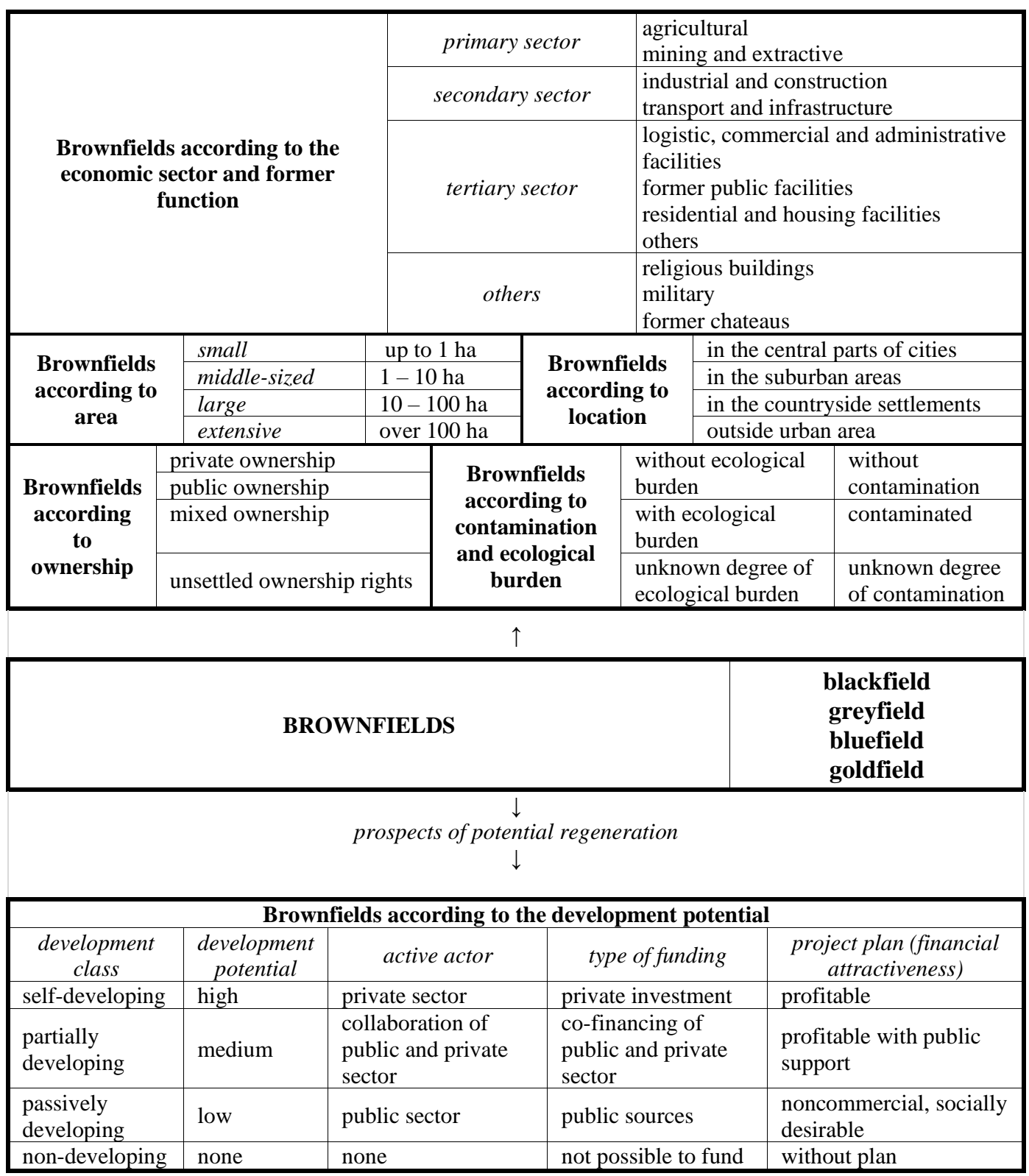


The next type (2) represent partially developing brownfields with a medium development potential, which will not be attractive for the private sector, both economically and socially, unless they get „moderate“ (financial and procedural) support from the public sector. For example, the decontamination costs or technical and transport infrastructure expenses will be covered by the public budget - in this way, the brownfield will become potentially more attractive for private investors and at the same time the private sector will allow for lower costs when regenerating this property. The third category (3) are brownfields that are unattractive for the private sector as they would not be able to generate any profit for this sector even in the long run. Here, the public sector should take responsibility, especially on the level of self-governing units, for the regeneration of these brownfields at its own expense provided it is socially desirable and in the public interest. The development potential of these brownfields is low and these properties are passively developing. The last group (4) are brownfields without development potential, the so-called non-developing. Society is indifferent to its existence and there are no undesirable implications for society as a whole. The regeneration of such brownfield is not necessary (is without a plan), not even by the intervention of the public sector.

\section{CONCLUSION}

Brownfields are frequently the subjects of research and it is essential to categorize or divide these abandoned and unused buildings and sites according to the required perspectives for the purposes of further research. Only appropriate and uniform classification of brownfields may predict their appropriate comparability and guarantee their meaningful analysis.

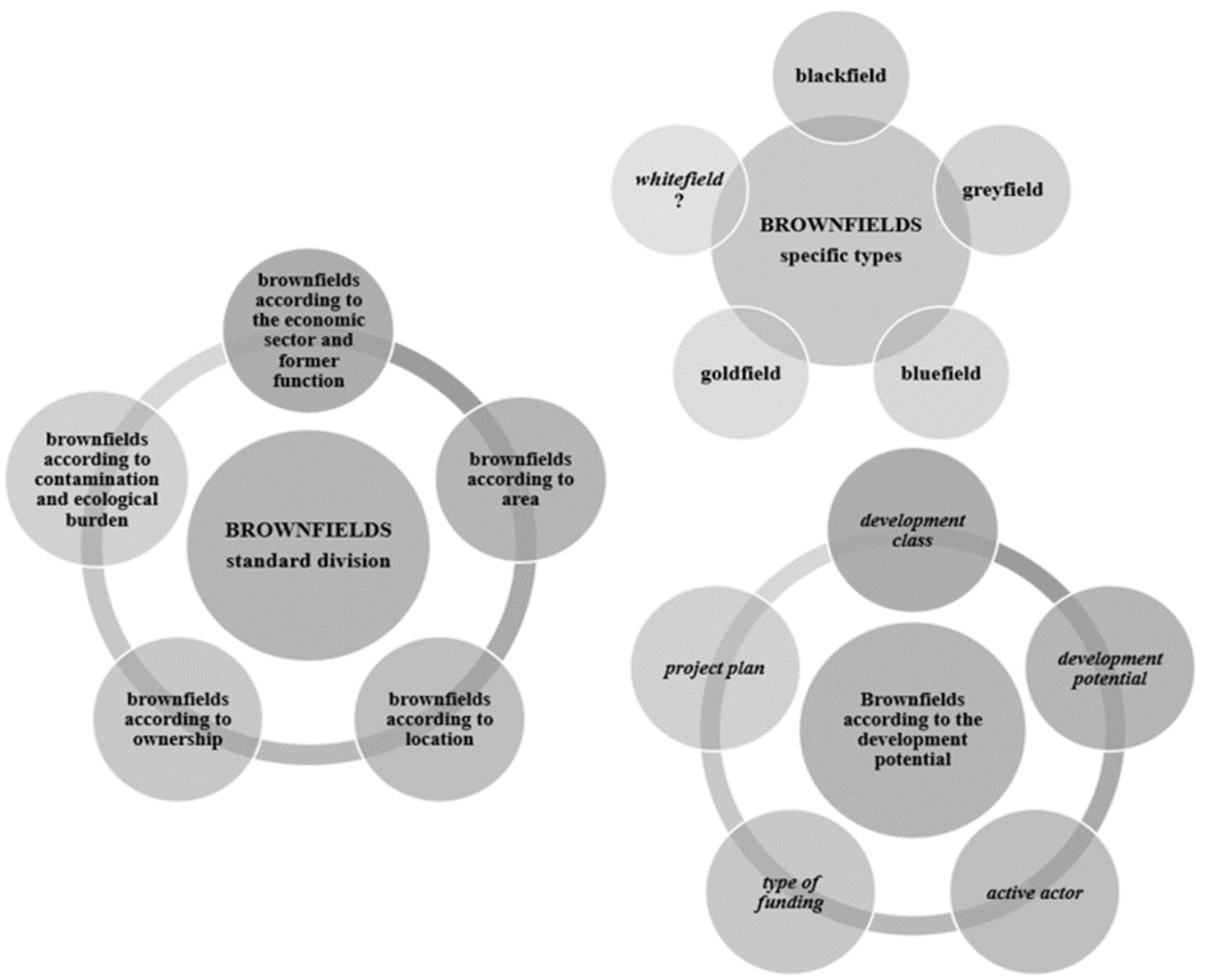

Fig. 3. Scheme of division and typology of brownfields. 
Based on a search of relevant resources this paper aimed to synthesize the heterogenous typology of brownfields into a complex and unified scheme that reflects both the content as well as the classification comprehensiveness and the logical interconnectedness of the selected classification of brownfields. This classification concerns the basic categories of brownfields and is subject to spatial, time and functional changes, in particular in the context of quantitative research. The presented categorization scheme defines ten typological groups of brownfields. Such performed synthesis of typological schemes and their objective categorization into standard classes and groups reflects the general requirements regarding the characteristics of brownfields and enables to define the individual brownfields according to a uniform method and further analyse them using the standardized categories.

At the same time, specific types of abandoned and unused buildings and sites were defined and a specific term was used for each of them representing the individual qualities of the individual brownfield. One of them is blackfield that is typical for its high level of concentration of ecological burden, followed by greyfield which is surrounded by vast grey areas of concrete and asphalt formerly used as a car park. Bluefield refers to the interconnection of water areas and sources, and goldfield, which is profitable and attractive for private investors once it has been regenerated as it is supposed to generate substantial profit in the future. These specific types of brownfields were supplemented with whitefield representing the least frequent type of brownfield and its existence is still controversial among the experts. Such comprehensive categorization of brownfields has never been published so far. In the field of further research, the specified categorization of brownfields can be used in the creation of databases, time and spatial comparison or in combination with other quantitative-statistical methods (cluster, factor, correspondence analysis, etc.).

In conclusion, it is essential to say that the categorization of brownfields may be approached from a broader perspective and they can be defined based on viewpoints that reflect the local needs or the needs of the concrete research plans. Their variability and quantity are extensive and it was not the aim of this paper to mention it here. The criterium for the selection of the above-mentioned classification scheme was uniformity, general applicability and the requirement to be the most frequently quoted brownfield classification among the relevant expert resources.

\section{ACKNOWLEDGMENT}

This paper was supported by the project SGF/7/2020 „The measures of the public sector for the strengthening of the regeneration potential of brownfields in the area of the Czech Republic".

\section{R E F E R E N C E S}

Alker, S., Joy, V., Roberts, P. \& Smith, N. (2000) The definition of brownfield. Journal of Environmental Planning and Management, 43 (1), 49-69. ISSN: 0964-0568. DOI 10.1080/09640560010766

Bartke, S. \& Schwarze, R. (2015) No perfect tools: Trade-offs of sustainability principles and user requirements in designing support tools for land-use decisions between greenfields and brownfields. Journal of environmental management, 153, 11-24.

Bergatt Jackson, J. \& Votoček, J. (2010) Metodika inventarizace brownfieldů v úrovni ORP. Available from: http://www.usti-nadlabem.cz/files/Metodika.pdf [Accessed February 2021].

Brownfields příručka, (2006) Brownfields príručka. Available from: http://fast10.vsb.cz/lepob/index2/handbook_cz_screen.pdf [Accessed February 2021].

De Sousa, C. A. (2003) Turning brownfields into green space in the City of Toronto. Landscape and urban planning, 62 (4), 181-198.

Duží, B. \& Jakubínský, J. (2013) Dilemma of Brownfields Redevelopment in Post-Communist Cities. The Case Study of Ostrava: the Czech Republic. Human Geographies, 7 (2), 53-64. ISSN 1843-6587

Dvořáková Lišková, Z., Vojvodíková, B. \& Majstríková, T. (2016) Základy brownfieldů v ekonomických souvislostech. Praha: Jihočeská univerzita v Českých Budějovicích.

Ferber et al. (2006) Sustainable brownfield regeneration: CABERNET network report. Nottingham: University of Nottingham. 
Frantál, B. (2015) Have local government and public expectations of wind energy project benefits been met? Implications for repowering schemes. Journal of Environmental Policy \& Planning, 17 (2), 217-236.

Heatherington, C., Jorgensen, A. \& Walker, S. (2019) Understanding landscape change in a former brownfield site. Landscape research, 44, (1), 19-34. DOI: 10.1080/01426397.2017.1374359

Jackson, J. B. et al. (2004) Brownfields snadno a lehce: Př́ručka zejména pro pracovníky a zastupitele obcí. IURS - Institut pro udrţitelný rozvoj sídel o. s.

Jankových-Kirschner, V. (2005) Klasifikace brownfields: Studie k disertační práci regenerace brownfields. Praha: České vysoké učení technické. Fakulta Architektury.

Kadeřábková, B. \& Piecha, M. (2009) Brownfields: jak vznikají a co s nimi. Praha: C. H. Beck.

Doležalová, L. (2015) Regenerace brownfieldů: vývoj politik a př́klady realizací. Praha: IREAS, Institut pro strukturální politiku.

Kibert, Ch. J. (2008) Sustainable Construction: Green Building Design and Delivery. Hoboken: John Wiley \& Sons. ISBN978-0-470-11421-6

Kirschner, V. (2006) Regenerace brownfields jako odpověd' na zastavování krajiny kolem měst. Urbanismus a územní rozvoj, 9 (2), 34-39. ISSN 1212-0855

Klusáček, P., Krejčí, T., Kunc, J., Martinát, S. \& Nováková, E. (2011) The post-industrial landscape in relation to local self-government in the Czech Republic. Moravian Geographical Reports, 19 (4), 8-28. ISSN 12108812

Krzystofik, R., Kantor-Pietraga, I. \& Spórna, T. (2013) A Dynamic Approach to the Typology of Functional Derelict Areas (Sosnowiec, Poland). Moravian Geographical Reports, 21 (2), 20-35.

Martinát, S. et al. (2015) Spatial relations and perception of brownfields in old industrial region: case study of Svinov (Ostrava, Czech Republic). Organization and Environment, 27 (2), 181-201. ISSN: 1086-0266

Martinát, S., Dvořák, P., Frantál, B., Klusáček, P., Kunc, J., Navrátil, J., Turečková, K. \& Reed, M., (2016) Sustainable urban development in a city affected by heavy industry and mining? Case study of brownfields in Karvina, Czech Republic. Journal of Cleaner Production, 118 (1), 78-87.

Mihaescu, O. \& vom Hofe, R. (2012) The impact of brownfields on residential property values in Cincinnati, Ohio: A spatial hedonic approach. Journal of Regional Analysis \& Policy, 42 (3), 223-236.

Moeller, D. W. (2011) Environmental Health. 4th ed. London: Harvard College. ISBN 978-06-74047-40-2

Naveed, A., Zhu, Y., Ibrahim, M., Waqas, M. \& Waheed, A. (2018) Development of a Standard Brownfield Definition, Guidelines, and Evaluation Index System for Brownfield Redevelopment in Developing Countries: The Case of Pakistan. Sustainability, 10 (4347).

Navrátil, J., Picha, K., Martinát, S., Nathanail, P. C. Turečková, K. \& Holešínská, A. (2018) Resident's preferences for urban brownfield revitalization: Insights from two Czech cities. Land Use Policy, 76 (1), 224-234. ISSN: 0264-8377. DOI: 10.1016/j.landusepol.2018.05.013.

Pinch, P. \& Munt, I. (2002) Blue Belts: An Agenda for 'Waterspace' Planning in the UK. Planning Practice and Research, 17 (2), 159-174.

Pizzol, L., Zabeo, A., Klusáček, P., Giubilato, E., Critto, A., Frantál, B., Martinát, S., Kunc, J., Osman, R. \& Bartke, S. (2016) Timbre brownfield prioritization tool to support effective brownfield regeneration. Journal of Environmental Management, 166, 178-192.

Schädler, S., Morio, M., Bartke, S., Rohr-Zänker, R. \& Finkel, M. (2011) Designing Sustainable and Economically Attractive Brownfield Revitalization Options Using an Integrated Assessment Model. Journal of Environmental Management, 92 (3), 827-837.

Spilková, J. \& Šefrna, L. (2010) Uncoordinated new retail development and its impact on land use and soils: A pilot study on the urban fringe of Prague, Czech Republic. Landscape and Urban Planning, 94 (2), 141-148.

Sun, W. \& Jones, B. (2013) Using multi-scale spatial and statistical analysis to assess the effects of brownfield redevelopment on surrounding residential property values in Milwaukee County, USA. Moravian Geographical Reports, (2), 56-64.

Šilhánková, V. et al. (2006) Rekonverze vojenských brownfields. Pardubice: Univerzita Pardubice.

Turečková, K. (2014) Quaternary sector as a source of growth and competitiveness in the EU. In: Proceedings of the 2nd International Conference on European Integration 2014. Ostrava: VŠB-TU Ostrava, 723-730.

Turečková, K. \& Chmielová, P. (2018) Brownfieldy v regionálním rozvoji a v externalitní teorii. In: XXI. mezinárodní kolokvium o regionálních vědách. Brno: MU ESF Brno, 302-308. ISBN 978-80-210-8969-3 
Turečková, K., Martinát, S., Škrabal, J., Chmielová, P. \& Nevima, J. (2017) How local population perceive impact of brownfields on the residential property values: some remarks from post-industrial areas in the Czech Republic. Geographia Technica, 12 (2), 150-164.

Turečková, K., Nevima, J., Škrabal, J. \& Martinát, S. (2018) Uncovering patterns of location of brownfields to facilitate their regeneration: Some remarks from the Czech Republic. Sustainability, 10 (6), 224-234.

Turečková, K., Nevima, J., Škrabal, J. \& Tuleja, P. (2019) Categorization of Impact of the Selected Variables for Potential Brownfield Regeneration in the Czech Republic by Means of Correspondence Analysis. Geographia Technica, 14 (2), 120-130.

Ústav pro ekopolitiku, o. p. s. (2006) Revitalizace „brownfields“v ČR. Available from: http://www.ekopolitika.cz/cs/ brownfields/revitalizace-brownfields-v-cr.html [Accessed January 2020].

Vojvodíková, B. et al. (2014) Brownfieldy - a co s nimi souvisí. Praha: European Science and Art Publishing. ISBN 978-80-87504-23-9

Vráblík, P. et al. (2009) Metodika revitalizace území pro hospodářský, sociální a environmentální rozvoj v postižených regionech. Available from: http://fzp.ujep.cz/projekty/wd-44-07-1/dokumenty/dc03 /DC003_Metodika_revitalizace_uzemi.pdf [Accessed February 2019].

Yakhlef, M. \& Abed, A. (2019) Identification of Brownfield Sites, Classification and Typologies Case Study of Amman, Jordan. Journal of Engineering and Applied Sciences, 14 (10), 3144-3149.

Yount, K. R. (2003) What are brownfields? Finding a conceptual definition. Environmental Practice, 5 (1), 25 33.

Suchacek J. (2019) The Benefit of Failure: On the Development of Ostrava's Culture. Sustainability, 11 (9), 2592. https://doi.org/10.3390/su11092592

Turečková, K., Nevima, J., Duda, D. \& Tuleja, P. (2021) Latent Structures of Brownfield Regeneration: A Case Study of Regions of the Czech Republic. Journal of Cleaner Production, 311(127478). DOI: https://doi.org/10.1016/j.jclepro.2021.127478.

Jackson, J. (2002) Urban Sprawl. Urbanismus a území rozvoj, 5 (6), 21-28.

Norrman, J. et al. (2015) BALANCE 4P: Balancing decisions for urban brownfield redevelopment. Available from: https://publications.lib.chalmers.se/records/fulltext/231843/local_231843.pdf [Accessed May 2021].

Bakker, J., Frangopol, D. M. \& van Breugel, K. (2016) Life-Cycle of Engineering Systems: Emphasis on Sustainable Civil Infrastructure. In: Proceedings of the Fifth International Symposium on Life-Cycle Civil Engineering (IALCCE 2016), 2016. Delft, The Netherlands. 